\title{
POTENTIAL FOR OBTAINING AN ULTRAFINE MICROSTRUCTURE OF LOW-CARBON STEEL USING ACCUMULATIVE ROLL BONDING
}

\author{
MOŽNOSTI DOSEGANJA ULTRADROBNOZRNATE \\ MIKROSTRUKTURE PRI SPAJANJU MALOOGLJIČNEGA JEKLA Z \\ AKUMULATIVNIM VALJANJEM
}

\author{
Tomáš Kubina, Jaroslav Gubiš \\ COMTES FHT, Prumyslova 995, 33441 Dobrany, Czech Republic \\ tkubina@comtesfht.cz \\ Prejem rokopisa - received: 2014-07-30; sprejem za objavo - accepted for publication: 2014-09-18
}

doi:10.17222/mit.2014.136

\begin{abstract}
The objective of the present work was to trial the ARB method on commercially available steels with the mass fraction of carbon $0.011 \%$. Specimens were prepared with great care, mainly with respect to their surfaces and shapes, to successfully achieve, at an elevated temperature, a mass reduction $50 \%$ in a single pass. The specimens were protected against scale formation at testing temperatures of $500-600{ }^{\circ} \mathrm{C}$. Due to the complexity of the ARB method, only two bonding cycles were completed. The initial mean grain size was $(18 \pm 7) \mu \mathrm{m}$; after the first ARB cycle, the grains had a length of $(24 \pm 10) \mu \mathrm{m}$ and a width of $(8 \pm 3) \mu \mathrm{m}$. The ultrafine-grained surface layer had a thickness of approximately 150-200 $\mu \mathrm{m}$. After the second ARB cycle, the microstructure of this type was found in the centre of the specimens. After two passes the strength reached $660 \mathrm{MPa}$, but the elongation dropped to $3.3 \%$. The ultimate strength of the annealed feedstock was $(290 \pm 3) \mathrm{MPa}$ and its elongation was $A_{50}(49 \pm 2) \%$. Experience shows that a continuous bonding of the material would be more effectively achieved with coiling machines, preventing the problems arising from the cracks in the welded joints on the faces of the specimens.

Keywords: low-carbon steel, accumulative roll bonding, microstructure, mechanical properties
\end{abstract}

Cilj predstavljenega dela je bil preizkus ARB-metode pri komercialnih jeklih z masnim deležem ogljika $0,011 \%$. Vzorci so bili pripravljeni z veliko pazljivostjo glede površine in oblike, da bi uspešno dosegli pri povišani temperaturi 50-odstotno zmanjšanje debeline v enem prehodu. Vzorci so bili zaščiteni pred nastankom škaje pri temperaturah preizkusa $500-600{ }^{\circ} \mathrm{C}$. Zaradi kompleksnosti ARB-metode sta bila dokončana samo dva cikla povezovanja. Začetna srednja velikost zrn je bila (18 \pm 7 ) $\mu \mathrm{m}$, po prvem ARB-ciklu so bila zrna dolga $(24 \pm 10) \mu \mathrm{m}$ in široka $(8 \pm 3) \mu \mathrm{m}$. Površinski sloj ultradrobnih zrn je bil debel okrog 150-200 $\mu \mathrm{m}$. Po drugem ARB-ciklu je bila podobna mikrostruktura tudi v sredini vzorca. Trdnost je po dveh prehodih dosegla $660 \mathrm{MPa}$, raztezek pa se je zmanjšal na 3,3\%. Končna trdnost žarjenega surovca je bila (290 \pm 3$)$ MPa, raztezek $A_{50}$ pa $(49 \pm 2) \%$. Izkušnje kažejo, da bi bilo spajanje materiala bolj učinkovito $\mathrm{Z}$ uporabo navijalcev, kar bi preprečilo težave s pojavom razpok v zvarjenih spojih na čelni strani vzorca.

Ključne besede: maloogljično jeklo, spajanje z akumulativnim valjanjem, mikrostruktura, mehanske lastnosti

\section{INTRODUCTION}

Severe-plastic-deformation (SPD) methods belong to the techniques for producing fine-grained microstructures of metals, whereby a material's strength is improved by the grain-size strengthening mechanism. It is achieved by imparting extremely high stresses and applying a large plastic deformation with a shear stress to the metals. In conventional forming processes, such as forging, rolling or ordinary extrusion, the accumulated imparted strain $\varepsilon$ is normally less than 2 . When a larger strain is applied, e.g., by rolling, the product becomes very thin and unsuitable for structural applications. To date, about a dozen methods for achieving fine-grained microstructures have been developed by applying a large plastic deformation with a strain level of more than 2 , while preserving the workpiece dimensions. ${ }^{1}$ When a large plastic strain is imparted, dislocations become absorbed by subgrain boundaries. Low-angle boundaries thus become high-angle boundaries (a misorientation angle of $\theta>10^{\circ}$ ) and the grain size is decreased. ${ }^{2}$ The most significant and currently most frequently used SPD methods include ARB (accumulative roll bonding), ECAP (equal-channel angular pressing) and its various variants and the HPT (high-pressure torsion) method.

ARB was developed by the team of prof. Saito in Japan in 1999. The method essentially involves stacking and bonding the stacked metal sheets by repeated cold rolling or warm rolling. The bonding is achieved by bringing the surfaces of metal sheets close together and by the resulting atomic-level interaction. Therefore, an essential precondition for creating a joint is a high quality of the surfaces. The surfaces of the metal sheets are prepared by grinding and degreasing. After the rolling, the rolled workpiece is split into halves and the surfaces of both parts are finished using the same procedure. The feedstock prepared in this manner is stacked again for the next processing cycle. ${ }^{3}$ 
In theory, a material can undergo the bonding, splitting and stacking sequences numerous times. Thus, the number of manufacturing cycles could be high as the material's final thickness does not change in the process. However, the achievable number of passes is limited by work-hardening processes and by surface-quality deterioration. Most references mention the maximum number of 5-10 passes. ${ }^{4-6}$ The rolling is typically carried out at elevated temperatures below the material recrystallization temperature to prevent the release of the accumulated strain energy due to recrystallization. Typical rolling temperature for low-carbon steels are shown in Table 1. References ${ }^{7-9}$ were selected according to the smallest grain size achieved. Otherwise, the effect of the process would be lost. On the other hand, low temperatures lead to an inadequate joint quality and to the cracking caused by impaired formability.

Table 1: Overview of the parameters and results achieved with the ARB method

Tabela 1: Pregled parametrov in rezultati, dobljeni z ARB-metodo

\begin{tabular}{|c|c|c|c|c|c|}
\hline \multirow{3}{*}{$\begin{array}{c}\text { Rolling } \\
\text { temperature } \\
{ }^{\circ} \mathrm{C}\end{array}$} & \multirow{3}{*}{$\begin{array}{l}\text { Number } \\
\text { of cycles }\end{array}$} & \multirow{3}{*}{$\begin{array}{l}\text { Applied } \\
\text { strain }\end{array}$} & \multicolumn{2}{|c|}{ Grain size } & \multirow{3}{*}{ Source } \\
\hline & & & before & after & \\
\hline & & & $\mu \mathrm{m}$ & $\mu \mathrm{m}$ & \\
\hline 500 & 7 & 5.6 & 20 & $0.2-0.3$ & 7 \\
\hline 550 & 8 & 6.4 & $5-27$ & $<0.1$ & 8 \\
\hline 500 & 5 & 6.4 & 30 & $<0.5$ & 9 \\
\hline
\end{tabular}

\section{EXPERIMENTAL WORK}

The experimental material was plain low-carbon steel supplied by the Třinecké železárny company. Its chemical composition (Table 2) was in accordance with the ČSN 411300 standard $^{10}$ and selected on the basis of the survey of the references. In the majority of the available studies $^{3,4,11,12}$ an IF steel was used and the composition of the present steel is closest to that of the IF steel. Continuously cast slabs of $150 \mathrm{~mm} \times 150 \mathrm{~mm} \times 350 \mathrm{~mm}$ were forged in a universal hydraulic press at $1200{ }^{\circ} \mathrm{C}$. The finish-forging temperature was $900{ }^{\circ} \mathrm{C}$. The dimensions of the final forgings were approximately $95 \mathrm{~mm} \times$ $147 \mathrm{~mm} \times 500 \mathrm{~mm}$. The forgings were annealed in a roller-hearth furnace for $60 \mathrm{~min}$ at $1200{ }^{\circ} \mathrm{C}$ and then rolled at the same temperature to a thickness of $8 \mathrm{~mm}$. The hot-rolled condition was chosen as the initial condition of the material. A two-high rolling mill with rolls of a $550 \mathrm{~mm}$ diameter was used for this purpose.

Table 2: Chemical composition of the initial continuously cast slab in mass fractions, $w / \%$

Tabela 2: Kemijska sestava začetnega kontinuirno ulitega slaba v masnih deležih, $w / \%$

\begin{tabular}{|c|c|c|c|c|c|c|}
\hline $\mathrm{C}$ & $\mathrm{Si}$ & $\mathrm{Mn}$ & $\mathrm{P}$ & $\mathrm{S}$ & $\mathrm{Cr}$ & $\mathrm{Mo}$ \\
\hline 0.011 & 0.022 & 0.159 & 0.006 & 0.015 & 0.037 & 0.001 \\
\hline $\mathrm{Cu}$ & $\mathrm{Al}$ & $\mathrm{As}$ & $\mathrm{B}$ & $\mathrm{Ce}$ & $\mathrm{N}$ & $\mathrm{Fe}$ \\
\hline 0.009 & 0.002 & 0.002 & 0.009 & $<0.003$ & 0.003 & 99.691 \\
\hline
\end{tabular}

Before the cold rolling the scale was removed from the hot-rolled sheets using a belt sander with the P80and P320-grit abrasives. The sheets of $7.7 \mathrm{~mm}$ were cold-rolled to a thickness of $2 \mathrm{~mm}$ in a four-high rolling mill with diameter rolls $240 \mathrm{~mm}$, coated with a protective film against decarburization and then recrystallization annealed at $700{ }^{\circ} \mathrm{C}$ for $2 \mathrm{~h}$. The metal sheets treated in this manner were then used for making input specimens for the ARB process.

The future contact surfaces of these specimens were degreased using acetone and then roughened by grinding or scrubbing. The leading edges of the specimens were spot-welded together and the trailing ends were tied together with the wires running through pre-drilled holes. The leading edges were ground to a wedge shape to facilitate the entry into the roll gape. The deformation was carried out in a single step with a constant reduction of $50 \%$ in all the passes. The specimens were heated in a HERAEUS electric furnace filled with nitrogen to suppress surface oxidation. As the furnace was stationed next to the rolling mill, the rolling temperature was only slightly lower than the soaking temperature (by $5{ }^{\circ} \mathrm{C}$ to $10{ }^{\circ} \mathrm{C}$ ). The specimens prepared for the second pass were first descaled by pickling in Clark's solution, then the same sequence was used as with the specimens for the first pass: grinding with the P40-grit abrasive, spot welding the corners of the leading edge and tying the trailing ends with wires. Details of the procedure are given $\mathrm{in}^{13}$.

After the tests aimed at finding suitable processing conditions, a set of 10 specimens was made using a single cycle, of which 5 specimens were prepared for the second ARB cycle. The specimens were heated in the HERAEUS furnace at $515{ }^{\circ} \mathrm{C}$ in nitrogen with a flow rate of $40 \mathrm{~L} / \mathrm{min}$ and after the soaking for $5 \mathrm{~min}$ the rolling was immediately performed.

The microstructures of all the rolled specimens at all the stages were examined using optical and electron microscopy. Metallographic sections were prepared by means of a Struers Discotom-6 grinding and polishing machine using the program for metallographic preparation of steels. The etchant used in all the cases was nital $(5 \%$ HNO3 + ethanol + methanol). Micrographs were taken using a Nikon Epiphot 200 light microscope with the NIS Elements 2.3 software for image digital processing, analysing and assessing the grain size. EBSD mapping was carried out using a JEOL 7400F microscope with a field-emission cathode. The instrument is provided with a HKL NORDLYS high-speed EBSD camera. The specimens for EBSD mapping were electrolytically polished using a Movipol polisher. In order to determine the spatial grain orientation more accurately, the pole figures in individual EBSD maps were evaluated as well.

The hardness values for the hot-rolled, cold-rolled and recrystallized sheets were measured using a Struers Durascan automatic hardness tester with the Workflow software. The hardness-depth profiles of the specimens 
were measured after one and two ARB cycles. Tensiontest plots were obtained by means of a Zwick/Roell Z250 testing machine. The tension tests were carried out according to the ČSN EN ISO 6892-1 standard. ${ }^{14}$

\section{RESULTS AND DISCUSSION}

The quality of the joint was controlled primarily with the presence of the oxide layer, whose thickness depended on the access of oxygen to the surface, and on the duration and the temperature of the soaking. Various combinations of these parameters showed that the most effective means of heating the specimens was the electric furnace with nitrogen gas. Soaking for $5 \mathrm{~min}$ led to relatively sound joints which are described in the following section. In an effort to reduce the soaking time, induction heating was tried as well. The technical conditions, however, did not allow the nitrogen atmosphere to be used. This drawback outweighs the benefits of rapid heating. Induction heating also proved inadequate because it caused a non-uniform heating and cracking.

It is believed that to obtain a quality joint, a higher surface hardness is required as it supports the adhesion between the materials. ${ }^{12}$ Another factor in selecting the surface-preparation method was its speed and ease of application because in the investigation no substantial impact of the surface-preparation technique on the joint quality was found. This was probably due to the fact that the study involved a large number of variables with a stronger impact on the quality of the joint than that of the sheet surface. As a result, grinding with a P40 abrasive wheel was selected for the surface preparation.

Figure 1 shows the microstructure of the sheet annealed at $700{ }^{\circ} \mathrm{C}$ for $2 \mathrm{~h}$ with equiaxed grains and a uniform grain size of $(15 \pm 7) \mu \mathrm{m}$ on the transverse cross-section and of $(18 \pm 7) \mu \mathrm{m}$ on the longitudinal cross-section. The longitudinal cross-section shows that recrystallization transformed the deformed and elongated grains into finer and undeformed grains. The only discer-

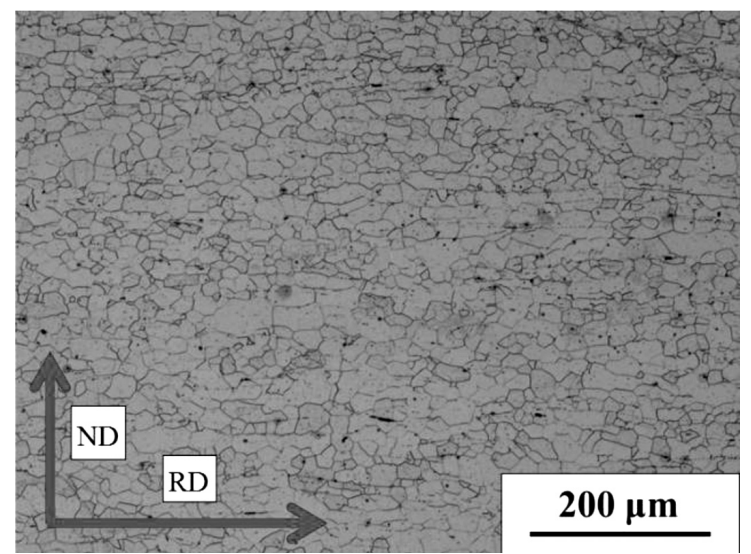

Figure 1: Microstructure of the longitudinal section through the recrystallization-annealed sheet

Slika 1: Mikrostruktura vzdolžnega prereza rekristalizacijsko žarjene pločevine nible trace of cold forming is the orientation of inclusions which was not changed by recrystallization.

The microstructure after the first ARB cycle is shown in Figure 2. Again, there is a surface layer of ultrafine grains with a thickness of $150-200 \mu \mathrm{m}$. There is also a

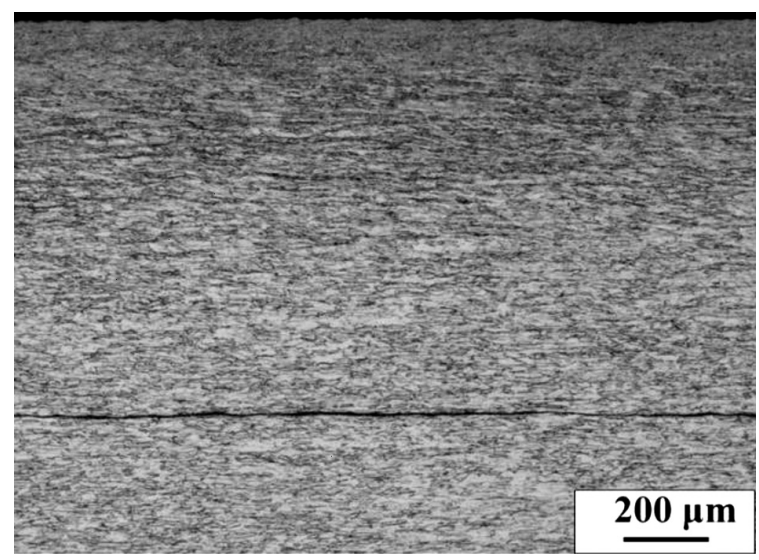

Figure 2: Surface layer and joint in the specimen after one ARB cycle Slika 2: Površinski sloj in spoj v vzorcu po enem ARB-ciklu

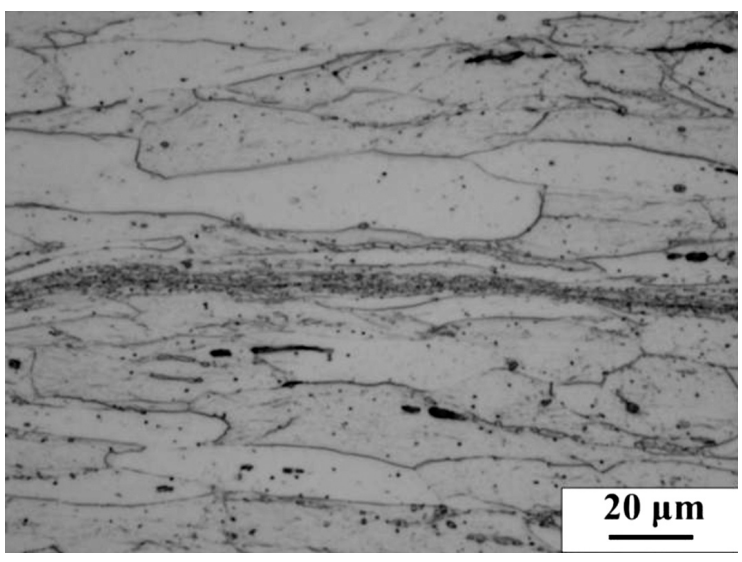

Figure 3: Detail of the joint in the specimen after one ARB cycle Slika 3: Detajl spoja v vzorcu po enem ARB-ciklu

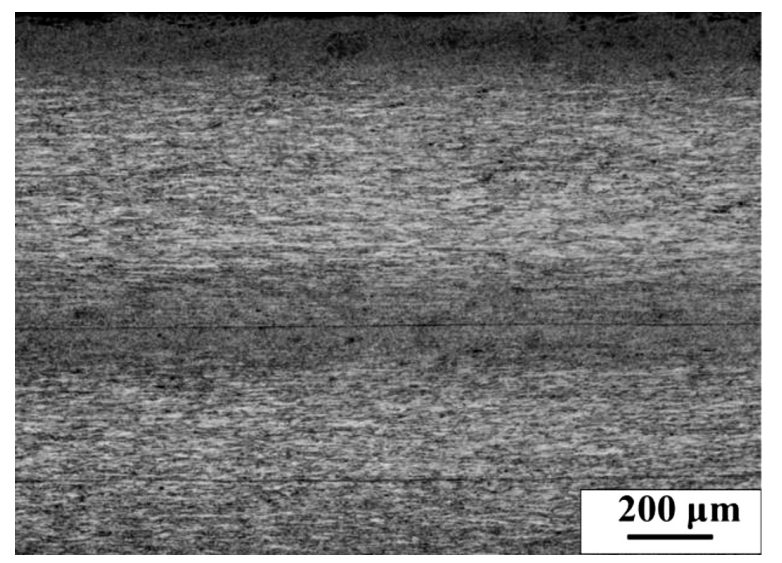

Figure 4: Microstructure of the sheet in the longitudinal direction after two ARB cycles

Slika 4: Mikrostruktura pločevine v vzdolžni smeri po dveh ARB-ciklih 


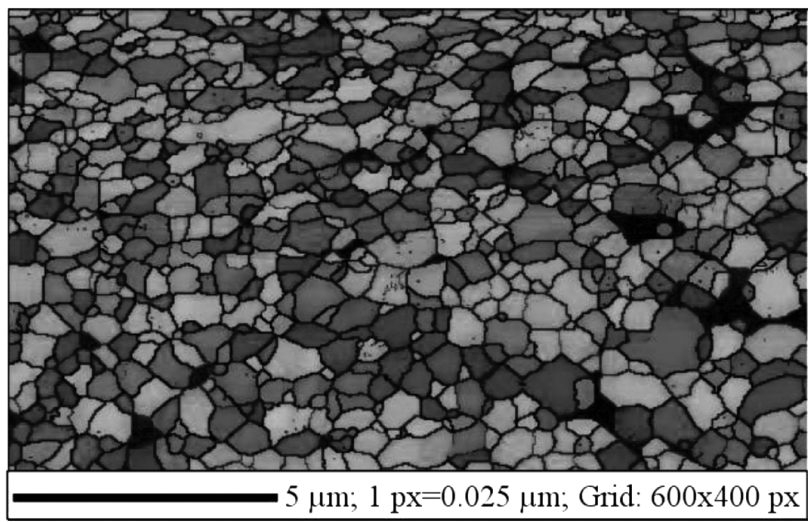

Figure 5: EBSD map of the area with fine grains in the specimen after two ARB cycles

Slika 5: EBSD-prikaz področja z drobnimi zrni v vzorcu po dveh ARB-ciklih

joint that appears to be of poor quality when viewed at a low magnification.

However, from Figure 3 it is clear that the joint is of good quality, consisting of very fine grains and being free of oxide. The formation of the thin layer of very fine grains in the joint can be attributed to a high friction in the area of the joint and to a high residual shear stress and its formation is described in detail in ${ }^{7}$.

The microstructure after two ARB cycles is shown in Figure 4. The original sheets and the joint created in the first cycle are clear to see. The quality of the first joint appears to be better than that of the second one and this is probably caused by an expansion of the joint area in the process. One can also observe an increased thickness of the layer of ultrafine grains, while the thickness of the surface layer remains to be $150-200 \mu \mathrm{m}$. This layer has a similar thickness even in the joint area. A detailed examination of the joint in the ultrafine-grained area from the previous pass reveals a very good joint quality without any traces of the oxide layer.

The specimen after two ARB cycles contained ultrafine grains only in the surface layer, as shown in Figure 5. The grains had exclusively high-angle boundaries and a uniform size. The mean grain size in the fine-grained area of the specimen after two ARB cycles was $700 \pm 300$ $\mathrm{nm}$, with the typical size being between $500 \mathrm{~nm}$ and 600 $\mathrm{nm}$.

As expected, the hot-rolled sheet had a low hardness, (94 \pm 2 ) $\mathrm{HV}_{10}$, low yield strength and ultimate strength but a very good elongation level. The upper yield point $R_{\mathrm{H}}$ was $(269 \pm 17) \mathrm{MPa}$ and the lower yield point $R_{\mathrm{L}}$ was $(232 \pm 9) \mathrm{MPa}$; the ultimate strength $R_{\mathrm{m}}$ was $(298 \pm 9)$ $\mathrm{MPa}$ and the $A_{50}$ elongation was $(40 \pm 2) \%$. The $\mathrm{HV}_{10}$ hardness of the cold-rolled sheet was $(196 \pm 2)$, which is twice the initial level. No distinct yield point was present in the tensile-test plot of this sheet. Its strength was of (770 \pm 2$) \mathrm{MPa}$, but the $A_{50}$ elongation level was lowered to $(1.8 \pm 0.1) \%$. This is evidence of intensive work hardening, while the low elongation reflects the loss of the material's ability to deform plastically.
In the recrystallization-annealed sheet the uniform and undeformed microstructure was restored, having the $\mathrm{HV}_{10}$ hardness of $(98 \pm 12)$, which is the same as for the hot-rolled sheet. The $R_{\mathrm{p} 0.2}$ proof stress decreased to (180 $\pm 5) \mathrm{MPa}$ and the ultimate strength to $(290 \pm 3) \mathrm{MPa}$, while the $A_{50}$ elongation level rose to $(49 \pm 2) \%$ and the distinct yield point vanished.

The $\mathrm{HV}_{0.1}$ hardness after a single ARB cycle is 270 near the surface and decreases gradually to approximately 200 in the centre. With respect to the tensile properties, compared to the cold-rolled and recrystallization-annealed sheets, the expected increase in the ultimate and yield strengths and a decrease in the elongation took place. The ultimate strength of the sheet after a single ARB cycle was $(611 \pm 36) \mathrm{MPa}$, the $A_{50}$ elongation was lowered to $(3.4 \pm 0.6) \%$ and the yield strength was $(609 \pm 20) \mathrm{MPa}$. The large scatter in the ultimate strength levels is possibly due to the variation in the thickness of the ultrafine-grained surface layer. A substandard quality of the joint in some locations of the tested specimen cannot be ruled out either.

The surface hardness measured in the specimens after two cycles is similar to that of the recrystallized specimen after a single cycle. The $\mathrm{HV}_{0.1}$ hardness of the surface layer is essentially identical to that of the specimen after a single cycle; it is 270 . However, the decrease in the hardness towards the specimen centre is slower. The minimum level is around 225. In addition, the hardness begins to rise again at a depth of approximately $0.7 \mu \mathrm{m}$, eventually reaching 245 and it is due to the ultrafine microstructure formed during the previous cycle in the centre of the specimen. In the specimen from the A2 series after two ARB cycles, the $R_{\mathrm{p} 0.2}$ proof stress was $(633 \pm 7) \mathrm{MPa}$, the strength was $(650 \pm 19) \mathrm{MPa}$ and the $A_{50}$ elongation was $(3.3 \pm 0.3) \%$. In Figure 6 the tensile-test plots for the cold-rolled and recrystallized materials are compared with those for the specimens after one and two ARB cycles. A large increase in the strength after the first cycle is clear to see, as the initial

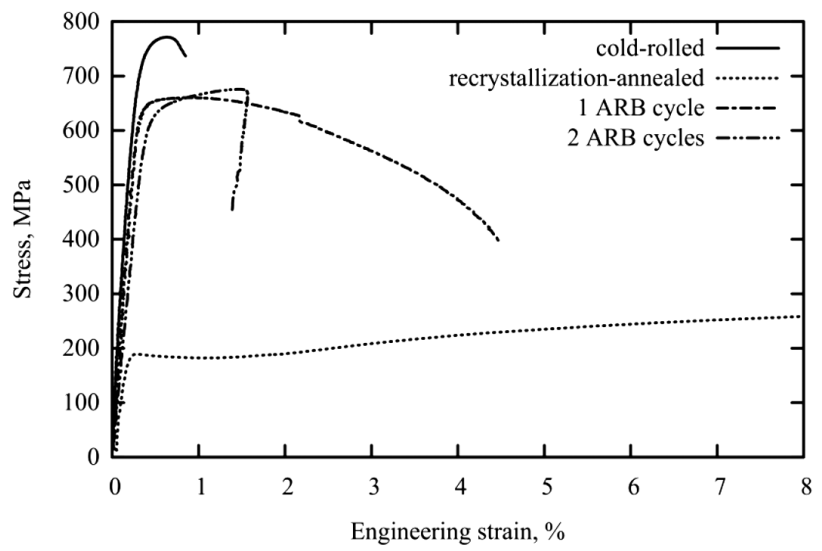

Figure 6: Comparison of the measured tensile curves after various treatments

Slika 6: Primerjava izmerjenih krivulj pri nateznem preizkusu po različnih obdelavah 
value was doubled. The next cycle led to a further increase in the strength, though not as large. Still, the highest strength was found in the cold-rolled sheet, which can be attributed to a different condition of its microstructure.

\section{CONCLUSION}

1. The conditions for rolling plain low-carbon steel and the ARB method used in a semi-commercial rolling mill in order to obtain a sound joint and ultrafine steel microstructure are investigated. As the appropriate rolling conditions, $5 \mathrm{~min}$ soaking at $515{ }^{\circ} \mathrm{C}$ in the electric furnace with nitrogen atmosphere and rolling at a $50 \%$ reduction in a single pass were determined. As the suitable locations for the spot welds, the corners of a specimen leading edge were confirmed. In this way the longitudinal cracks that could initiate in the weld location were minimized. The heating in the furnace with an inert atmosphere provided reproducible conditions for the trials.

2. By means of the ARB rolling process, an ultrafinegrained surface layer with a thickness of 150-200 $\mu \mathrm{m}$ was obtained. The size of the smallest grains was 200 $\mathrm{nm}$ and the mean grain size was $700 \mathrm{~nm}$. The grains were uniform, recrystallized and did not exhibit any notable orientation with regard to the rolling plane. In the next cycle, the ultrafine microstructure formed in the centre of the specimen; we assume that with more cycles it would spread throughout the specimen thickness.

3. The ultrafine-grained layer had an increased hardness of $300 \mathrm{HV}_{0.1}$, the ultimate strength was doubled and the yield strength was almost tripled with respect to the annealed material. After two passes, the ultimate strength reached $660 \mathrm{MPa}$, while the elongation dropped to $3.3 \%$.

4. In future experiments, the method of joining the specimens will be welding as the latest trials showed that longitudinal cracks occur even on the appropriately located welds due to the effects of the heating in the vicinity of the weld. However, in this study induction heating was found to be unsuitable.

5. With the realised tests uniform heating was not achieved and, as a result, cracks appeared on the specimens. Rapid heating and an inert atmosphere are some of the conditions required for preventing an oxide layer from developing on the surfaces to be joined. A fine-tuned induction heating would provide a uniform and rapid heating in inert gas and may offer a wide field of application.

6. The work hardening rapidly decreased the material plastic deformability. For this reason, heat-treatment options will be explored more closely in future experiments, with the aim to retain the ultra-fine microstructure and increase the elongation above $10 \%$.

\section{Acknowledgement}

The paper was prepared under the West-Bohemian Centre of Materials and Metallurgy project no. CZ.1.05/2.1.00/03.0077, with the support from the European Regional Development Fund.

\section{REFERENCES}

${ }^{1}$ A. Azushima et al., CIRP Annals - Manufacturing Technology, 57 (2008) 2, 716-735, doi:10.1016/j.cirp.2008.09.005

${ }^{2}$ Z. R. Valiev, G. L. Terence, Progress in Materials Science, 51 (2006) 7, 881-981, doi:10.1016/j.pmatsci.2006.02.003

${ }^{3}$ Y. Saito, H. Utsunomiya, N. Tsuji, T. Sakai, Acta Metall. Mater., 47 (1999) 2, 579-583, doi:10.1016/S1359-6454(98)00365-6

${ }^{4}$ N. Tsuji et al., Scripta Materialia, 47 (2000) 12, 893-899, doi:10.1016/S1359-6462(02)00282-8

${ }^{5}$ S. Tamimi et al., Materials and Design, 30 (2009), 2556-2562, doi:10.1016/j.matdes.2008.09.039

${ }^{6}$ Y. Okitsu, N. Takata, N. Tsuji, Scripta Materialia, 64 (2011) 9, 896-899, doi:10.1016/j.scriptamat.2011.01.026

${ }^{7}$ N. Kamikawa, N. Tsuji, Y. Minamino, Science and Technology of Advanced Materials, 5 (2004) 1-2, 163-172, doi:10.1016/j.stam. 2003.10.018

${ }^{8}$ A. A. Tohidi, M. Ketabachi, A. Hassania, Mater. Sci. Eng. A, 577 (2013), 43-47, doi:10.1016/j.msea.2013.04.025

${ }^{9}$ A. Kolahi, A. Akbarzadeh, M. R. Bernett, Journal of Materials Processing Technology, 209 (2009) 3, 1436-1444, doi:10.1016/ j.jmatprotec.2008.03.064

${ }^{10}$ ČSN 41 1300. 41 - Hutnictví - Materiálové Listy Ocelí 4113 - Oceli třídy 11, Material data sheets, 1986

${ }^{11}$ S. Lee, Y. Saito et al., Mater. Trans. JIM, 43 (2000) 9, 2320-2325, doi: $10.2320 /$ matertrans.43.2320

${ }^{12}$ G. Krallics, J. G. Lenard, Journal of Materials Processing Technology, 152 (2004), 154-161, doi:10.1016/j.jmatprotec.2004.03.015

${ }^{13}$ J. Gubiš, Vlastnosti ultrajemnozrnné oceli připravené metodou intenzivní plastické deformace, Diploma thesis, Institute of Chemical Technology Prague, Faculty of Chemical Technology, Department of Metallic Materials and Corrosion Engineering, Praha, 2014

${ }^{14}$ ČSN EN ISO 6892-1, Kovové materiály - Zkoušení tahem - Část 1: Zkušební metoda za pokojové teploty, Praha: Úřad pro technickou normalizaci, metrologii a státní zkušebnictví, 2010, 64 pages 